\title{
Soybean Industrial Seed Treatment: Effect on Physiological Quality During Storage
}

\author{
C. R. Bork ${ }^{1}$, A. S. Almeida ${ }^{2}$, C. S. Castellano², G. Zimmer², T. D. Avila 2 , G. E. Meneghello², S. M. Dellaostin², \\ D. B. Rodrigues ${ }^{2}$, F. Mattos ${ }^{2}$, C. Rossetti ${ }^{2}$, H. W. Fonseca ${ }^{2}$, C. Tunes ${ }^{2}$, A. S. Suñé2, B. Barreto ${ }^{2}$, \\ L. M. Tunes ${ }^{2} \&$ L. O. B. Suchch ${ }^{2}$ \\ ${ }^{1}$ IFSUL, Pelotas, RS, Brazil \\ ${ }^{2}$ Federal University of Pelotas, Capão do Leão, RS, Brazil \\ Correspondence: A. S. Almeida, Federal University of Pelotas, Capão do Leão, CEP 96010-610, RS, Brazil. \\ E-mail: andreiasalmeida@yahoo.com.br
}

Received: April 6, 2018

doi:10.5539/jas.v10n8p468
Accepted: May 18, $2018 \quad$ Online Published: July 15, 2018

URL: https://doi.org/10.5539/jas.v10n8p468

\begin{abstract}
The aim of this study was to analyze soybean seed physiological quality after being subjected to various mixtures of pesticides via industrial seed treatment. The experiment was performed at the seed laboratory of the company BioGrow, located at São Paulo-SP, using soybean seeds cultivar NS 6700 IPRO which were subjected to 11 different treatments. Seed treatment was carried out using a treater Momesso, model L5-K, calibrated to apply a spray volume of $0.5 \mathrm{~L} 100 \mathrm{~kg}^{-1}$ of seeds in which the volume of each treatment was adjusted using distilled water. After treatment, seeds were spread over plastic strays for drying for a period of 24 hours under environmental conditions. Once dry, seeds were packed in paper bags and stored for 0 (control), 45, 90, 135 and 180 days, under uncontrolled conditions of temperature and relative humidity, when seed physiological quality was evaluated using the following tests: germination, accelerated aging, seedling emergence, speed of emergence index and speed of emergence. Soybean industrial seed treatment before storage for up to 180 days is practicable using the mixtures of pesticides tested for storing seeds under environmental conditions. All treatments tested contribute to the maintenance of seed quality throughout storage.
\end{abstract}

Keywords: Glycine max, germination, vigor

\section{Introduction}

Soybean (Glycine max L. Merrill) has wide expression in the commodity market due to a major socioeconomic value which is determined by the numerous uses of products and byproducts on human and animal feed. World production, at the 2016/2017 crop season, was of 315.1 million tons, occupying 118.1 million of hectares (USDA, 2015). Brazil is the second greater soybean world producer, with a production of 94.8 million tons and a cultivated area of 31.4 million hectares (IBGE, 2016).

Various advances in soybean production technology have allowed the increase in area and crop yield in the recent years, among them is the quality of seeds used. According to Baudet and Peske (2007), and Silva (1998), uniform seed germination and vigorous growth of seedlings at the onset of crop development are essential to guarantee the maximum yield potential genetically contained. Likewise, Baudet and Peres (2004) observed that seeds with high germination, field emergence and growth potential can produce a uniform plant stand which results in high crop yields. However, seeds are sown at the field being exposed to numerous biotic (pests and diseases) and abiotic factors which impair physiological performance, affecting germination and reducing seedling emergence uniformity. Thus, to protect seeds and seedlings against a set of adversities, phytosanitary products as fungicides and insecticides are applied to the seeds (Ludwig et al., 2011; Pereira et al., 2011).

According to Avelar et al. (2011) soybean seed treatment is economically recommended, provided that the products or mixture of products used are adequate, using the recommended dosage and are uniformly distributed throughout the seed lot.Additionally, Lucca Filho (2006) determined that an efficient chemical treatment must select a product which is able to eradicate the pathogens present in the seeds, non-toxic to the crop, humans and the environment, non-corrosive, presents high stability, adherence and coverage, low cost and easy access, besides being compatible with other products. 
Concomitantly with the increasing perception of the value of seeds and of the importance of protecting/increasing performance, the availability of products for seed treatmentfor different purposes has grown, such as protection (fungicides or insecticides) or nutrition (micronutrients), aiming to improve seed performance, both physiologically and economically (Avelar et al., 2011). However, besides increasing seed protection and assisting seedling initial development, the products and mixtures of products used in seed treatment shall not interfere negatively the physiological quality of seed lots, both immediately after treatment or during the storage period.

Accordingly, the present study aimed to analyze seed physiological quality after being subjected to various mixtures of products via seed treatment.

\section{Method}

The experiment was performed at the seed laboratory of BioGrow, located in São Paulo-SP, using soybean seeds cultivar NS 7600 IPROsubjected to 11 different treatments described in Table 1.

Table 1. Treatment Identification (TR); commercial product used; active ingredient; concentration of the active ingredient contained in each product; dosage of the commercial product used and class of the product

\begin{tabular}{|c|c|c|c|c|c|}
\hline TR & $\begin{array}{l}\text { Name of the } \\
\text { commercial product }\end{array}$ & Active ingredient (i.) & $\begin{array}{l}\text { Concentration } \\
\left(\text { g a. i. } \mathbf{L}^{-1}\right)\end{array}$ & $\begin{array}{l}\text { Dosage of the } \\
\text { commercial product } \\
\left(\mathrm{mL} 100 \mathrm{~kg}^{-1} \text { of seeds) }\right.\end{array}$ & Class of the product \\
\hline TR-1 & Control & Without treatment & & & \\
\hline \multirow[t]{2}{*}{ TR-2 } & Maxim XL & Fludioxonil & 25 & 100 & Fungicide \\
\hline & & Metalaxyl-M & 10 & & \\
\hline \multirow[t]{3}{*}{ TR-3 } & NUF $323 \mathrm{~F} 1535 \mathrm{FS}$ & Azoxystrobin & 130 & 100 & Fungicide \\
\hline & & Fluazinam & 105 & & \\
\hline & & Carbendazim & 300 & & \\
\hline \multirow[t]{3}{*}{ TR-4 } & NUF $323 \mathrm{~F} 1535 \mathrm{FS}$ & Azoxystrobin & 130 & 150 & Fungicide \\
\hline & & Fluazinam & 105 & & \\
\hline & & Carbendazim & 300 & & \\
\hline \multirow[t]{3}{*}{ TR-5 } & Maxim XL & Fludioxonil & 25 & 100 & Fungicide \\
\hline & & Metalaxyl-M & 10 & & \\
\hline & Standak Top & Fipronil & 250 & 200 & Insecticide \\
\hline \multirow[t]{3}{*}{ TR-6 } & Maxim XL & Fludioxonil & 25 & 100 & Fungicide \\
\hline & & Metalaxyl-M & 10 & & \\
\hline & Maestro FS & Fipronil & 250 & 200 & Insecticide \\
\hline \multirow[t]{4}{*}{ TR-7 } & NUF $323 \mathrm{~F} 1535 \mathrm{FS}$ & Azoxystrobin & 130 & 75 & Fungicide \\
\hline & & Fluazinam & 105 & & \\
\hline & & Carbendazim & 300 & & \\
\hline & Maestro FS & Fipronil & 250 & 200 & Insecticide \\
\hline \multirow[t]{3}{*}{ TR-8 } & NUF $323 \mathrm{~F} 1535 \mathrm{FS}$ & Azoxystrobin & 130 & 75 & Fungicide \\
\hline & & Fluazinam & 105 & & \\
\hline & & Carbendazim & 300 & & \\
\hline \multirow[t]{4}{*}{ TR-9 } & NUF $323 \mathrm{~F} 1535 \mathrm{FS}$ & Azoxystrobin & 130 & 75 & Fungicide \\
\hline & & Fluazinam & 105 & & \\
\hline & & Carbendazim & 300 & & \\
\hline & Biocoat GR Red & Film coater & - & 100 & \\
\hline \multirow[t]{5}{*}{ TR-10 } & NUF $323 \mathrm{~F} 1535 \mathrm{FS}$ & Azoxystrobin & 130 & 75 & Fungicide \\
\hline & & Fluazinam & 105 & & \\
\hline & & Carbendazim & 300 & & \\
\hline & Maestro FS & Fipronil & 250 & 200 & Insecticide \\
\hline & Biocoat GR Red & Film coater & - & 100 & \\
\hline \multirow[t]{5}{*}{ TR-11 } & NUF $323 \mathrm{~F} 1535 \mathrm{FS}$ & Azoxystrobin & 130 & 75 & Fungicide \\
\hline & & Fluazinam & 105 & & \\
\hline & & Carbendazim & 300 & & \\
\hline & Maestro FS & Fipronil & 250 & 200 & Insecticide \\
\hline & Biocoat GR Red & Film coater & - & 150 & \\
\hline
\end{tabular}


Seed treatment was performed using a treaterMomesso, Model L5-K, calibrated to apply a spray volume of $0.5 \mathrm{~L}$ $100 \mathrm{~kg}$ of seeds ${ }^{-1}$, in which the volume of each treatment was adjusted with distilled water. After treatment, seeds were distributed over plastic trays for drying for a period of 24 hours at room temperature. Once dried, seeds were placed into paper bags and stored for 0 (control), 45, 90,135 and 180 days, under uncontrolled conditions of temperature and relative humidity, when seed physiological quality was evaluated using the following tests:

Germination: performed using germitest paper rolls wetted with distilled water, in a volume of 2.5 times de weight of the dry paper. Seeds were distributed in four paper rolls of 50 seeds each, totaling 200 seeds per repetition, which were transferred for a germination chamber and held at a constant temperature of $25{ }^{\circ} \mathrm{C}$. Normal seedlings were counted at five and nine days after sowing accordingly to the Rules for Seed Testing (Brasil, 2009) and results were expressed in percentage.

Accelerated aging: carried outusing the gerbox method; seeds were disposed in a single layer over a wire mesh which was held suspended above $40 \mathrm{~mL}$ of distilled water. The gerbox were covered and transferred to a Biological Oxygen Demand (B.O.D.) chamber at $41{ }^{\circ} \mathrm{C}$ for 48 hours (Marcos Filho, 2005). Then, seeds were removed from the gerbox and placed to germinate in the conditions described for the germination test. The evaluation was performed at the fifth day after sowing, counting the number of normal seedlings and expressing the results in percentage.

Seedling emergence: performed in trays filled with sand as substrate, sowing four repetitions of 50 seeds per treatment. Sowing depth was of approximately three centimeters and irrigation was carried out daily, at early morning and late afternoon; the percentage of emerged seedlings was counted at 21 days after sowing.

Speed of emergence index (SEI): carried out alongside the seedling emergence test. The index was calculated for each repetition accordingly to the procedure proposed by Maguire (1962), using the following equation: SEI = $(\mathrm{G} 1 / \mathrm{N} 1)+(\mathrm{G} 2 / \mathrm{N} 2)+\ldots+(\mathrm{Gn} / \mathrm{Nn})$, where $\mathrm{G}$ is the number of normal seedlings emerged each day and $\mathrm{N}$ is the number of days after sowing in which the counting was performed.

Speed of emergence (SE): evaluated herewith the seedling emergence and calculated using the following equation $\mathrm{SE}=[(\mathrm{G} 1 \mathrm{~N} 1)+(\mathrm{G} 2 \mathrm{~N} 2)+\ldots+(\mathrm{GnNn})] /(\mathrm{G} 1+\mathrm{G} 2+\ldots+\mathrm{Gn})$. Where, $\mathrm{G}$ is the number of normal seedlings emerged at each day and $\mathrm{N}$ is the number of days after sowing in which the counting was carried out.

The experiment was performed as a $5 \times 11$ (storage periods $\times$ seed treatment) factorial under completely randomized design using four repetitions. Data processing was performed using R Software (R Core Team, 2014). Data were subjected to analysis of variance using the F-Test $(p<0.05)$ and, when significant differences were observed, a polynomial regression was calculated $(\mathrm{p}<0.05)$ for the factor storage period and means were compared using the least significative difference $(\mathrm{p}<0.05)$ for the factor seed treatment.

\section{Results}

According to the results of the analysis of variance, the storage period and the treatments applied presented a simple effect on the percentage of germination, however, there was no interaction between factors. Figure 1A presents the percentage of germinated seeds for each treatment applied where the control presented the greater percentage of germination (92.5\%) which did not differ statistically from treatments TR-2, TR-3, TR-6, TR-7 and TR-10. Likewise, treatments TR-4, TR-9 and TR-11 presented a statistically lower percentage of germination compared to the other treatments. Regarding the percentage of germination throughout storage (Figure 1B), the variable was adjusted to a negative quadratic model where the maximum germination of $93 \%$ was observed immediately after seed treatment, which correspond to time zero of storage. Then, seed germination decreased accordingly with the increase of the storage time. 

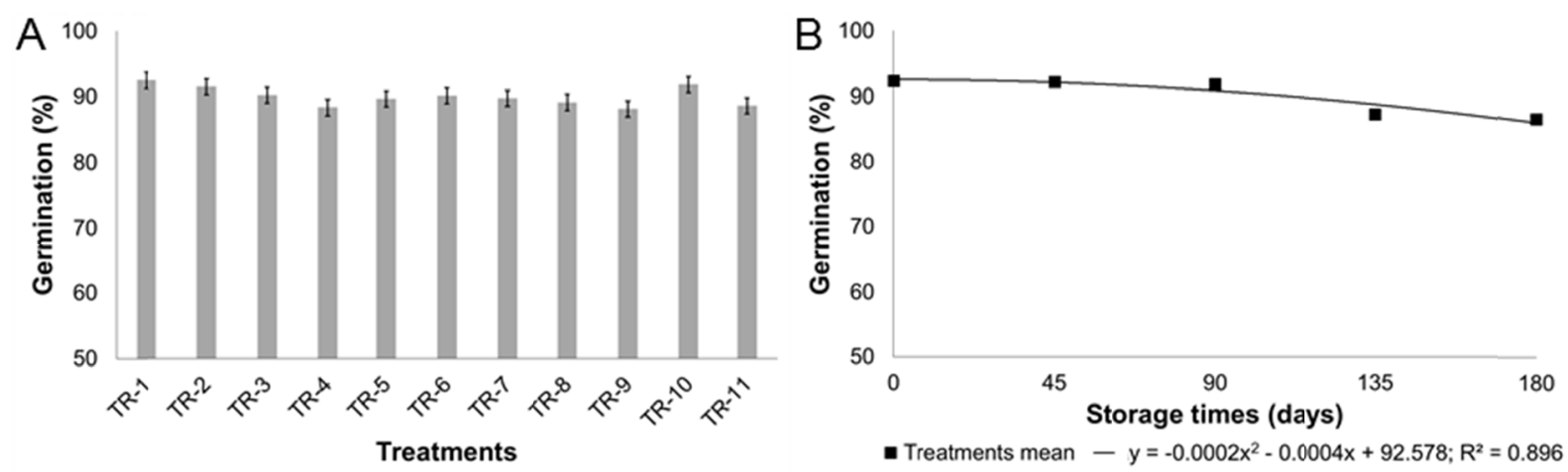

Figure 1. Germination percentage of soybean seeds cv. NS 6700 IPRO, in response to 11 seed chemical treatments (A) and to storage under uncontrolled conditions of temperature and relative humidity (B)

Note. TR-1: Control (without treatment); TR-2: Maxim XL (100 mL $100 \mathrm{~kg}^{-1}$ of seeds); TR-3: NUF 323F1 535 (100 mL $100 \mathrm{~kg}^{-1}$ of seeds); TR-4: NUF 323F1 $535 \mathrm{FS}$ (150 mL $100 \mathrm{~kg}^{-1}$ of seeds); TR-5: Maxim XL (100 mL $100 \mathrm{~kg}^{-1}$ of seeds) + Standak Top (200 mL $100 \mathrm{~kg}^{-1}$ of seeds); TR-6: Maxim XL (100 mL $100 \mathrm{~kg}^{-1}$ of seeds $)+$

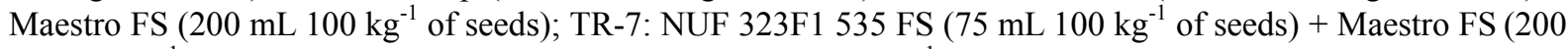
$\mathrm{mL} 100 \mathrm{~kg}^{-1}$ of seeds); TR-8: NUF 323F1 $535 \mathrm{FS}$ (75 mL $100 \mathrm{~kg}^{-1}$ of seeds); TR-9: NUF 323F1 $535 \mathrm{FS}$ (75 mL $100 \mathrm{~kg}^{-1}$ of seeds) + Film coater (100 mL $100 \mathrm{~kg}^{-1}$ of seeds); TR-10: NUF 323F1 $535 \mathrm{FS}$ (75 mL $100 \mathrm{~kg}^{-1} \mathrm{of}^{-1}$ seeds) + Maestro FS (200 mL $100 \mathrm{~kg}^{-1}$ of seeds) + Film coater (100 mL $100 \mathrm{~kg}^{-1}$ of seeds); TR-11: NUF 323F1 $535 \mathrm{FS}\left(75 \mathrm{~mL} 100 \mathrm{~kg}^{-1}\right.$ of seeds $)+$ Maestro FS $\left(200 \mathrm{~mL} 100 \mathrm{~kg}^{-1}\right.$ of seeds $)+$ Film coater $\left(100 \mathrm{~mL} 100 \mathrm{~kg}^{-1} \mathrm{of}^{-1}\right.$ seeds). $\mathrm{CV}=4.31 \%$. In Figure 1A, bars correspond to the LSD value (Least significant difference) between different seed treatments $(\mathrm{p}<0.05)$, therefore bars which overlap are statisticallyequal.

The analysis of variance demonstrated that the variable accelerated aging was affected by the interaction between the factors studied. Figure 2A shows that right after seed treatment, TR- 8 was statistically superior and TR-9 was statistically inferior while the remaining treatments did not differ between each other. After 45 days of storage, TR-6 was statistically inferior to the other treatments. In the other periods of storage $(90,135$ and 180 days), treatments TR-2, TR-9 and TR-10 were statistically superior to the remaining treatments, on the other hand, TR-5 presented the lower percentage of germinated seeds.

Treated seeds, when evaluated by the accelerated aging test, presented a linear decrease herewith the increase of storage time for all treatments studied, with exception of TR-9 which presented a quadratic behavior (Figures 2B and $2 \mathrm{C}$ ). The rate of vigor reduction varied from 0.02 to $0.1 \%$ day $^{-1}$ where treatments TR-4, TR-5, TR-6, TR-7, TR-8 and TR-11 presented the greater rates of vigor reduction (Figures $2 \mathrm{~B}$ and $2 \mathrm{C}$ ). In contrast, TR-9, due to the quadratic behavior, showed a maximum percentage of germinated seeds of $89 \%$ at the 81 days of storage (Figure 2C). 


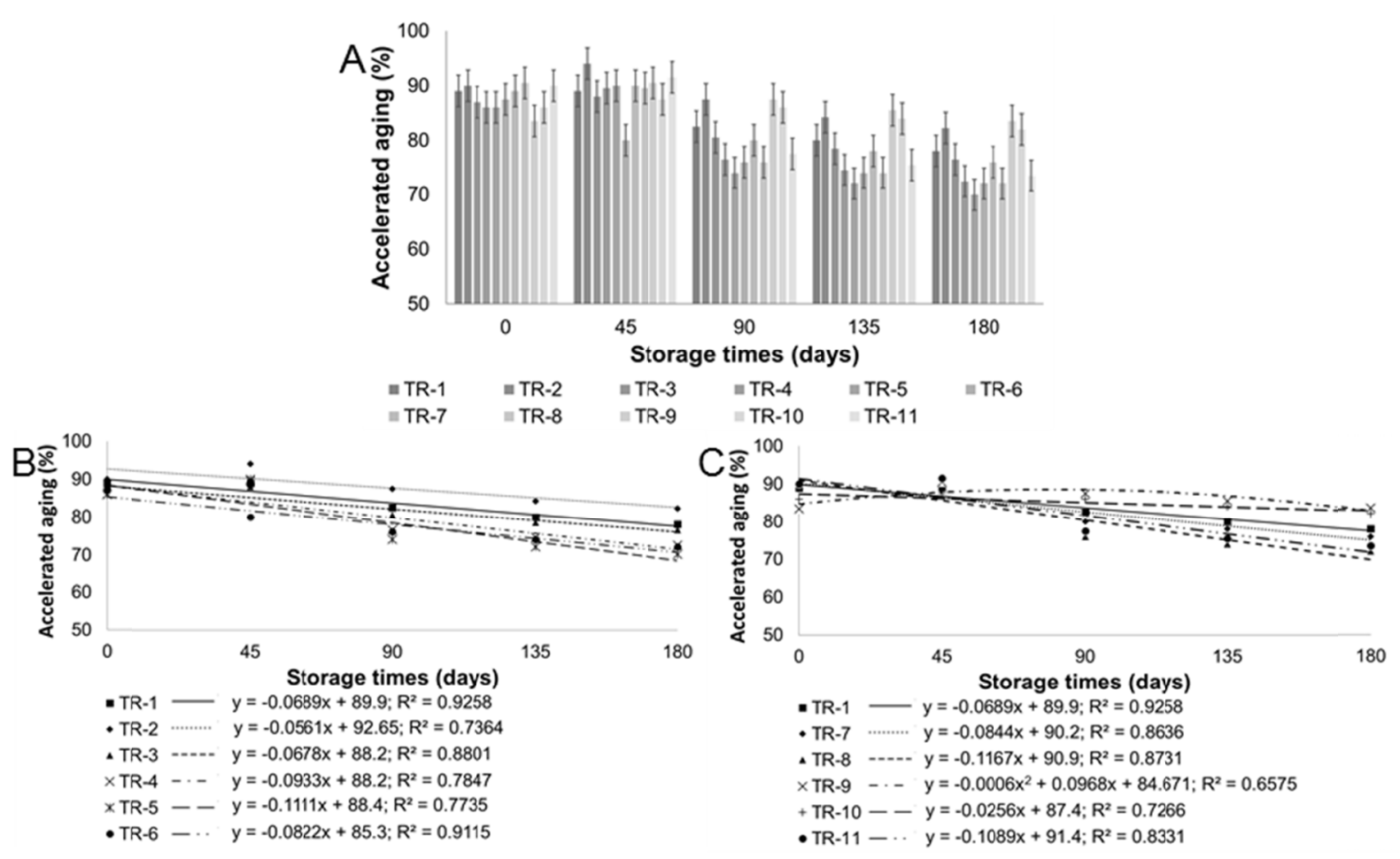

Figure 2. Vigor of soybean seeds cv. NS 6700 IPRO, evaluated by accelerated aging, in response to the interaction of 11 seed treatments with different chemicals (A) and the storage under uncontrolled conditions of temperature and relative humidity $(\mathrm{B}$ and $\mathrm{C})$

Note. TR-1: Control (without treatment); TR-2: Maxim XL (100 mL $100 \mathrm{~kg}^{-1}$ of seeds); TR-3: NUF 323F1 535 (100 mL $100 \mathrm{~kg}^{-1}$ of seeds); TR-4: NUF 323F1 $535 \mathrm{FS}$ (150 mL $100 \mathrm{~kg}^{-1}$ of seeds); TR-5: Maxim XL (100 mL $100 \mathrm{~kg}^{-1}$ of seeds) + Standak Top (200 mL $100 \mathrm{~kg}^{-1}$ of seeds); TR-6: Maxim XL (100 mL $100 \mathrm{~kg}^{-1}$ of seeds) +

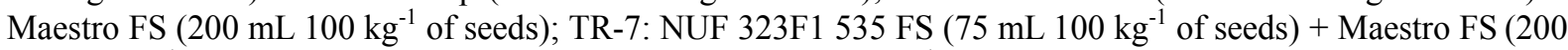
$\mathrm{mL} 100 \mathrm{~kg}^{-1}$ of seeds); TR-8: NUF 323F1 $535 \mathrm{FS}$ (75 mL $100 \mathrm{~kg}^{-1}$ of seeds); TR-9: NUF 323F1 $535 \mathrm{FS}$ (75 mL $100 \mathrm{~kg}^{-1}$ of seeds) + Film coater (100 mL $100 \mathrm{~kg}^{-1}$ of seeds); TR-10: NUF 323F1 $535 \mathrm{FS}$ (75 mL $100 \mathrm{~kg}^{-1} \mathrm{of}^{-1}$ seeds) + Maestro FS (200 mL $100 \mathrm{~kg}^{-1}$ of seeds) + Film coater (100 mL $100 \mathrm{~kg}^{-1}$ of seeds); TR-11: NUF 323F1 $535 \mathrm{FS}\left(75 \mathrm{~mL} 100 \mathrm{~kg}^{-1}\right.$ of seeds $)+$ Maestro FS (200 mL $100 \mathrm{~kg}^{-1}$ of seeds $)+$ Film coater $\left(100 \mathrm{~mL} 100 \mathrm{~kg}^{-1}\right.$ of seeds). $\mathrm{CV}=4.99 \%$. In Figure $2 \mathrm{~A}$, bars correspond to the LSD value (least significant difference) between different seed treatments $(\mathrm{p}<0.05)$, therefore bars which overlap are statisticallyequal.

Seedling emergence in sand showed interaction between the factors tested, according to the analysis of variance. In Figure 3A the response of the treatments at each storage time is presented. At time zero, the control (TR-1) presented the lower number of emerged seeds. On the other hand, at 45 and 90 days there were no significant differences between treatments studied. At the 135 days of storage, TR-7 was statistically inferior to the remaining treatments while at 180 days of storage, treatments TR-1 and TR-6 were significantly inferior to the other treatments, where treatments TR- 8 and TR-10 presented the greater percentage of emerged seeds.

The behavior of seedling emergence in sand throughout storage demonstrated a quadratic negative model, reaching a maximum emergence of $96 \%$ at the 63 days of storage. Thereafter, emergence reduced overtime (Figure 3B). Treatments TR-2, TR-5 and TR-6 adjusted to a negative linear model, demonstrating rates of reduction of emergence in sand of $0.06 ; 0.04$ and $0.08 \%$ day $^{-1}$, respectively. The remaining treatments did not adjust to any mathematic models (Figures $3 \mathrm{~B}$ and $3 \mathrm{C}$ ). 


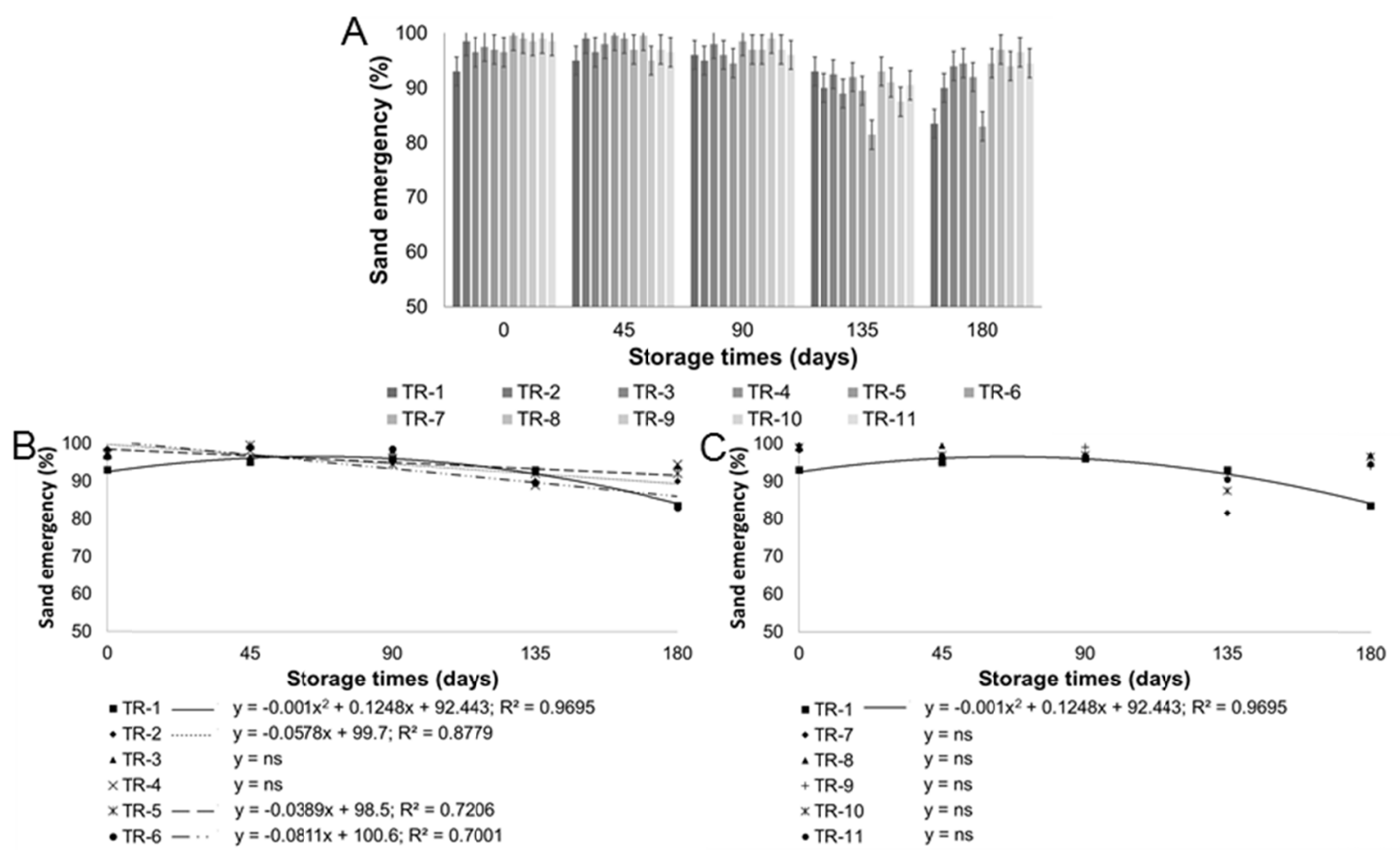

Figure 3. Vigor of soybean seeds cv. NS 6700 IPRO, evaluated by seedling emergence in sand, in response to the interaction of 11 seed treatments with different chemicals (A) and the storage under uncontrolled conditions of temperature and relative humidity $(\mathrm{B}$ and $\mathrm{C})$

Note. TR-1: Control (without treatment); TR-2: Maxim XL (100 mL $100 \mathrm{~kg}^{-1}$ of seeds); TR-3: NUF 323F1 535 (100 mL $100 \mathrm{~kg}^{-1}$ of seeds); TR-4: NUF 323F1 $535 \mathrm{FS}$ (150 mL $100 \mathrm{~kg}^{-1}$ of seeds); TR-5: Maxim XL (100 mL $100 \mathrm{~kg}^{-1}$ of seeds) + Standak Top (200 mL $100 \mathrm{~kg}^{-1}$ of seeds); TR-6: Maxim XL (100 mL $100 \mathrm{~kg}^{-1}$ of seeds) +

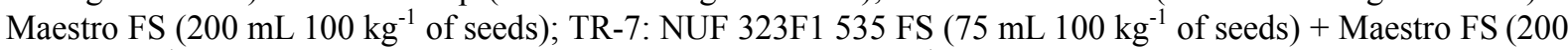
$\mathrm{mL} 100 \mathrm{~kg}^{-1}$ of seeds); TR-8: NUF 323F1 $535 \mathrm{FS}$ (75 mL $100 \mathrm{~kg}^{-1}$ of seeds); TR-9: NUF 323F1 $535 \mathrm{FS}$ (75 mL $100 \mathrm{~kg}^{-1}$ of seeds) + Film coater (100 mL $100 \mathrm{~kg}^{-1}$ of seeds); TR-10: NUF 323F1 $535 \mathrm{FS}$ (75 mL $100 \mathrm{~kg}^{-1} \mathrm{of}^{-1}$ seeds) + Maestro FS (200 mL $100 \mathrm{~kg}^{-1}$ of seeds) + Film coater (100 mL $100 \mathrm{~kg}^{-1}$ of seeds); TR-11: NUF 323F1

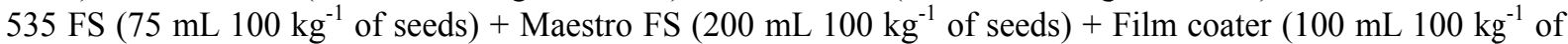
seeds). $\mathrm{CV}=3.98 \%$. In Figure $3 \mathrm{~A}$, bars correspond to the LSD value (least significant difference) between different seed treatments $(\mathrm{p}<0.05)$, therefore bars which overlap are statisticallyequal.

The speed of emergence index (SEI) also showed response to the interaction between the factors studied, according to the analysis of variance. In storage time zero TR-2 presented the greater SEI, followed by TR-1 and TR-4. TR-7, in contrast, demonstrated the lowest SEI of all treatments. At 45 days, TR-2 presented the higher SEI, followed by TR-9 and TR- 1 while TR-11 and TR-3 presented the lower SEI. At 90 days, TR-3, TR-6, TR-2 and TR-1 presented the higher SEI while TR-11 and TR-8 presented the lower performance. At 135 days, TR-1, TR-3 and TR-2 presented the higher SEI and TR-4, TR-8 and TR-7 the lower. Lastly, at 180 days TR-2, TR-10, TR-9 and TR-3 outperformed the remaining treatments wherein TR-11, TR-1 and TR- 6 presented the lower performances (Figure 4A).

The values of SEI presented a gradual decrease throughout storage (Figures 4B and 4C) which can be explained by a quadratic model in treatments TR-1, TR-2 and TR-9,reaching maximum values of 27.61; 28.19 and 26.74 at the 42,17 and 53 days of storage, respectively. 


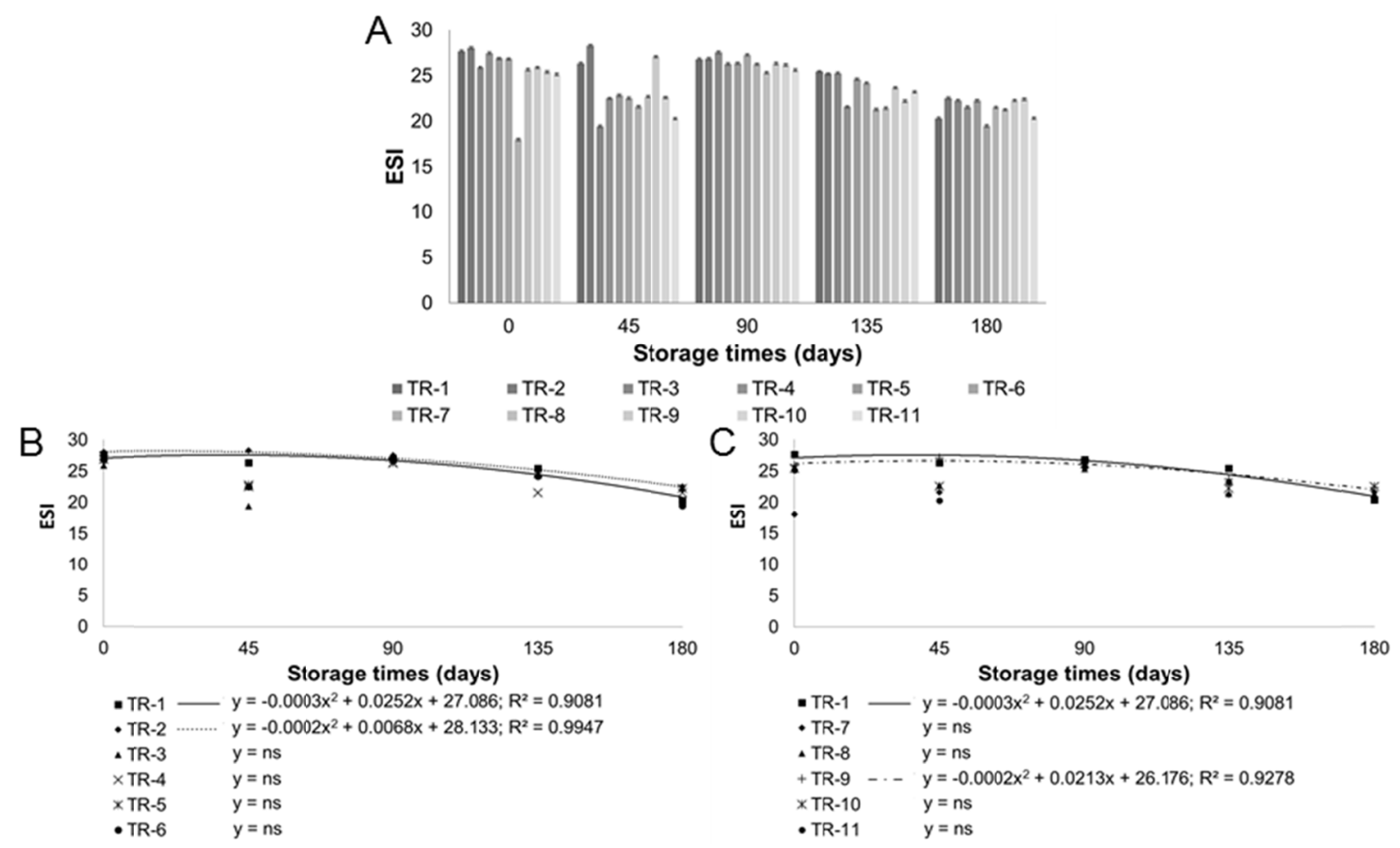

Figure 4. Vigor of soybean seeds cv. NS 6700 IPRO, evaluated by the speed of emergence index, in response to the interaction of 11 seed treatments with different chemicals (A) and storage under uncontrolled conditions of temperature and relative humidity $(\mathrm{B}$ and $\mathrm{C})$

Note. TR-1: Control (without treatment); TR-2: Maxim XL (100 mL $100 \mathrm{~kg}^{-1}$ of seeds); TR-3: NUF 323F1 535 (100 mL $100 \mathrm{~kg}^{-1}$ of seeds); TR-4: NUF 323F1 $535 \mathrm{FS}$ (150 mL $100 \mathrm{~kg}^{-1}$ of seeds); TR-5: Maxim XL (100 mL $100 \mathrm{~kg}^{-1}$ of seeds) + Standak Top (200 mL $100 \mathrm{~kg}^{-1}$ of seeds); TR-6: Maxim XL (100 mL $100 \mathrm{~kg}^{-1}$ of seeds) +

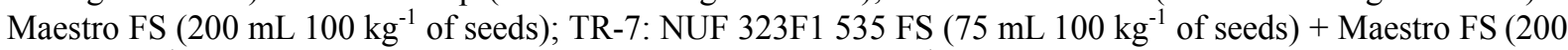
$\mathrm{mL} 100 \mathrm{~kg}^{-1}$ of seeds); TR-8: NUF 323F1 $535 \mathrm{FS}$ (75 mL $100 \mathrm{~kg}^{-1}$ of seeds); TR-9: NUF 323F1 $535 \mathrm{FS}$ (75 mL $100 \mathrm{~kg}^{-1}$ of seeds) + Film coater (100 mL $100 \mathrm{~kg}^{-1}$ of seeds); TR-10: NUF 323F1 $535 \mathrm{FS}$ (75 mL $100 \mathrm{~kg}^{-1} \mathrm{of}^{-1}$ seeds) + Maestro FS (200 mL $100 \mathrm{~kg}^{-1}$ of seeds) + Film coater (100 mL $100 \mathrm{~kg}^{-1}$ of seeds); TR-11: NUF 323F1

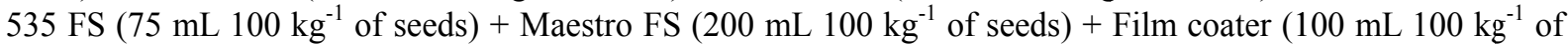
seeds). $\mathrm{CV}=0.68 \%$. In Figure $4 \mathrm{~A}$, bars correspond to the LSD value (least significant difference) between different seed treatments $(\mathrm{p}<0.05)$, therefore bars which overlap are statisticallyequal.

The results of the analysis of variance for speed of emergence demonstrated the simple effect of the factor time of storage. Figure 5 shows the behavior of this variable throughout storage which was adjusted to a positive linear model, with the increase in the days required for germination at a rate of 0.0127 days for each day of storage. However, this result must be interpreted cautiously as the coefficient of determination $\left(\mathrm{R}^{2}\right)$ obtained indicates that only $33 \%$ of the response variable variation observed is explained by the model proposed. 


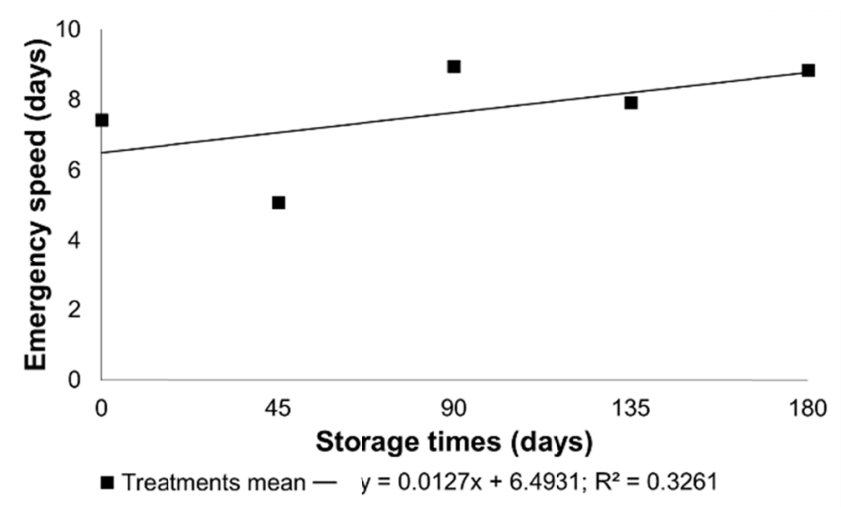

Figure 5. Speed of emergence of soybean seeds cv. NS 6700 IPRO, treated with different chemicals in response to storage under uncontrolled conditions of temperature and relative humidity

\section{Discussion}

Generally, the results obtained demonstrate that seed physiological quality was differentially affected by allseed treatments applied, wherein each vigor test performed entailed different behaviors for each seed treatment tested. However, the effect of storage time in seed physiological quality was remarkable, causing vigordecrease on all variables studied independently of the seed treatment tested.The results reported in this study corroborate with the findings of Dan et al. (2010), which evaluated the effect seed treatment with insecticides in the physiological quality of soybean seeds during storage and verified the decrease. Almeida et al. (2014) observed that vigor, which was measured by the accelerated aging test, of soybean seeds treated with various fungicides and insecticides before storage decreased with the increase of storage time. Likewise, Piccinin et al. (2013) detected the decrease of seed physiological quality of soybean seeds treated with fipronil and thiamethoxam and stored for 180 days. According to Horii and Shetty (2007), seed treatment with chemical products, in general, causes the reduction of the speed of emergence index (SEI) as the storage time increases. On the other hand, Pires et al. (2004) reported that seed treatment with polymers and fungicides did not affect bean seeds germination during storage for 120 days. Furthermore, Krohn and Malavassi (2004), which tested the effect of soybean seed treatment with fungicides before storage, did not observe the impairment of germination, however, emergence reduced when seeds were stored for more than 4 months after treatment.

Despite the statistical differences between seed treatments in each storage time evaluated and throughout storage, in this experiment there were no germination percentages inferior to $80 \%$, which is the minimum value required by legislation for soybean seed commercialization in Brazil. Therefore, seed industrial treatment may be performed before storage using any of the mixturestestedandwithout restrictions if seeds are stored for up to 180 days. Furthermore, the differences observed between each treatment tested may be attributed to the different active ingredients present in each pesticide. According to Ludwiget et al. (2011) the decrease of germination of seeds treated with pesticides may be caused by phytotoxic effects of the active ingredient.

\section{Conclusions}

The industrial seed treatment in soybean before is storage for up to 180 days is viable using the mixtures of pesticides and storage conditions tested in this study.

All treatments tested contributed to the maintenance of seed quality throughout storage.

\section{References}

Almeida, A. S., Castellanos, C. I. S., Deuner, C., Borges, C. T., \& Meneghello, G. E. (2014). Efeitos de inseticidas, fungicidas e biorreguladores na qualidade fisiológica de sementes de soja durante o armazenamento. Revista de Aricultura, 89(3), 172-182.

Avelar, S. A. G., Baudet, L., Peske, S. T., Ludwig, M. P., Rigo, G. A., Crizel, R. L., \& Oliveira, S. (2011). Storage of soybean seed treated with fungicide, insecticide and micronutrient and coated with liquid and powered polymer. Ciência Rural, 41(10), 1719-1725. https://doi.org/10.1590/S0103-84782011005000130

Baudet, L., \& Peres, W. B. (2004). Recobrimento de sementes. Seed News, 4(1), 20-23.

Baudet, L., \& Peske, F. (2007). Aumentando o desempenho das sementes. Seed News, 9(5), p.22-24. 
Brasil. (2009). Ministério da Agricultura, Pecuária e Abastecimento. Regras para análise de sementes. Brasília: MAPA/ACS.

Dan, L. G. de M., Dan, H. de A., Barroso, A. L. de L., \& Braccini, A. de L. E. (2010). Qualidade fisiológica de sementes de soja tratadas com inseticidas sob efeito do armazenamento. Revista Brasileira de Sementes, 32(2), 131-139. https://doi.org/10.1590/S0101-31222010000200016

Horii, P. M., \& Shetty, K. (2007). Enhancement of seed vigour following insecticide and phenolic elicitor treatment. Bioresource Technology, 98, 623-632. https://doi.org/10.1016/j.biortech.2006.02.028

IBGE (Instituto Brasileiro de Geografia e Estatística). (2016). Levantamento Sistemático de Produção Agrícola. Retrieved from http://www.ibge.gov.br/home/estatistica/indicadores/agropecuaria/lspa/lspa_201502_4.shtm

Krohn, N. G., \& Malavasi, M. de M. (2004). Qualidade fisiológica de sementes de soja tratadas com fungicidas durante e após o armazenamento. Revista Brasileira de Sementes, 26(2), 91-97. https://doi.org/10.1590/ S0101-31222004000200013

Lucca Filho, O. A. (2006). Patologia de Sementes. In S. T. Peske, O. A. Lucca Filho, \& A. C. S. A. Barros (Eds.), Sementes: Fundamentos cientificos e Tecnológicos (2nd ed., pp. 259-329) Pelotas, Brazil.

Ludwig, M. P., Lucca Filho, O. A., Baudet, L., Dutra, L. M. C., Avelar, S. A. G., \& Crizel, R. L. (2011). Qualidade de sementes de soja armazenadas após recobrimento com aminoácido, polímero, fungicida e inseticida. RevistaBrasileira de Sementes, 33(3), 395-406. https://doi.org/10.1590/S0101-31222011000 300002

Maguire, J. D. (1962). Speed of germination-aid selection and evaluation for seedling emergence and vigor. Crop Science, 2(2), 176-177. https://doi.org/10.2135/cropsci1962.0011183X000200020033x

Marcos Filho, J. (2005). Fisiologia de sementes de plantas cultivadas. Piracicaba: Fealq.

Pereira, C. E., Guimarães, R. M., Vieira, A. R., Evangelista, J. R. E., \& Oliveira, G. E. (2011). Tratamento fungicida e peliculização de sementes de soja submetidas ao armazenamento. Ciência Agrotécnica, 35(1), 158-164. https://doi.org/10.1590/S1413-70542011000100020

Piccinin, G. G., Braccini, A. L., Dan, L. G. de M., Bazo, G. L., \& Lima, L. H. da S. (2013). Influência do armazenamento na qualidade fisiológica de sementes de soja tratadas com inseticidas. Ambiencia, 9(2), 289-298. https://doi.org/10.5777/ambiencia.2013.02.04

Pires, L. L., Bragantini, C., \& Costa, J. L. S. (2004). Armazenamento de sementes de feijão revestidas com polímeros e tratadas com fungicidas. Pesquisa Agropecuária Brasileira, 39(7), 709-715. https://doi.org/ 10.1590/S0100-204X2004000700013

R Core Team. (2014). $R$ : A language and environment for statistical computing. Vienna, Austria: R Foundation for Statistical Computing. Retrieved from http://r-project.org

Silva, M. T. B. (1998). Inseticidas na proteção de sementes e plantas. Seed News, 2(5), $26-27$.

USDA (United States Department of Agriculture). (2015). World Agricultural Supply and Demand Estimates (WASDE). Retrieved from http://www.usda.gov/oce/commodity/wasde

\section{Copyrights}

Copyright for this article is retained by the author (s), with first publication rights granted to the journal.

This is an open-access article distributed under the terms and conditions of the Creative Commons Attribution license (http://creativecommons.org/licenses/by/4.0/). 